\title{
Insulin-like growth factor-1 promotes cell cycle progression via upregulation of cyclin D1 expression through the phosphatidy- linositol 3-kinase/nuclear factor-kB signaling pathway in FRTL thyroid cells
}

\author{
Meng REN ${ }^{1, \#, s}$, Xia ZHONG ${ }^{1, \#}$, Chun-yan $\mathrm{MA}^{1}$, Ying $\mathrm{SUN}^{2}$, Qing-bo GUAN ${ }^{1}$, Bin CUI ${ }^{1}$, Jun GUO ${ }^{1}$, Hai WANG ${ }^{1}$, Ling \\ $\mathrm{GAO}^{1, *}$, Jia-jun $\mathrm{ZHAO}^{1, *}$ \\ ${ }^{1}$ Shandong Provincial Hospital, Shandong University, Jinan 250021, China; ${ }^{2}$ Department of Endocrinology, Yantai Yuhuangding Hospital, Yantai 264000, \\ China
}

\begin{abstract}
Aim: Insulin-like growth factor-1 (IGF-1) is an important hypertrophic and cell cycle progression factor for a number of cell types. It has been proven that IGF-1 is involved in the regulation of thyroid proliferation and cell cycle progression; however, the exact mechanism of this regulation has not been fully elucidated. In the present study, we investigated the effect of IGF-1 on the expression of cyclin D1, an important cell cycle regulatory protein, and a signaling pathway involved in IGF-1's effect on cyclinD1 expression in FRTL thyroid cells.

Methods: FRTL thyroid cells were treated with IGF-1 or vector control for $24 \mathrm{~h}$. As appropriate to individual experiments, a phosphatidylinositol 3-kinase (PI3K) inhibitor, LY294002, and/or a nuclear factor-kB (NF-kB) inhibitor, BAY11-7082, were added $1 \mathrm{~h}$ prior to IGF-1 treatment. Western blotting was used to detect cyclin D1 protein expression. Immunofluorescence was performed to analyze the expression of IкBa, an NF-kB inhibitory protein. Cell cycle analysis was performed by fluorescence activated cell sorting (FACS).

Results: IGF-1 increased the cyclin D1 expression in thyroid cells. This increase was blocked by pretreatment with LY294002 or BAY11-7082. Further studies showed that IGF-1 specifically induced NF-kB activity. Treatment with IGF-1 could accelerate cell cycle progression from $G_{0} / G_{1}$ to $S$ phase, whereas this progression was inhibited by the presence of LY294002 or BAY11-7082.

Conclusion: In summary, the results of the present study show that in FRTL cells, IGF-1 promotes cell cycle progression via an upregulation of cyclin D1 expression, at least partially through the PI3K/NF-KB signaling pathway.
\end{abstract}

Keywords: insulin-like growth factor-1; phosphatidylinositol3-kinase; nuclear factor- $\mathrm{kB}$; cyclin D1

Acta Pharmacologica Sinica (2009) 30: 113-119; doi: 10.1038/aps.2008.8; published online 8th December 2008

\section{Introduction}

During the $G_{1}$ phase of the eukaryotic cell division cycle, signals transduced from activated growth factor receptors regulate progression through the cell cycle ${ }^{[1,2]}$. These signals can cause cells to either enter the $G_{1}$ phase of the cell cycle and divide or exit from the cell cycle. Cyclin D1

\footnotetext{
\# These authors contributed equally to this work.

${ }^{\S}$ Now in Department of Endocrinology, The Second Affiliated Hospital of Sun Yat-sen University, Guangzhou 510120, China.

* Correspondence to Dr Jia-jun ZHAO and Dr Ling GAO.

E-mail jj_zhao61@yahoo.com.cn; gaoling@medmail.com.cn

Received 2008-07-27 Accepted 2008-10-20
}

is a $G_{1}$ phase cell cycle protein. Accumulation of this kind of protein by stimulation of extracellular signals promotes cell proliferation. It has been reported that in thyroid papillary carcinomas the expression of cyclin D1 is elevated; this elevation is thought to be a contributory factor in thyroid tumorigenesis ${ }^{[3]}$. However, information is limited regarding the relationship between cyclin D1 and growth factors as well as the relevant signaling pathway in normal thyroid cells.

Insulin-like growth factor-1 (IGF-1) has been widely proven to regulate cell proliferation and an array of other cell functions. Furthermore, IGF-1 is believed to be an important hypertrophic and cell cycle progression factor for a number of cell types ${ }^{[4,5]}$. However, the specific signaling 
pathways involved in the effect of IGF-1 on cyclin D1 expression and cell cycle progression in thyroid cells have been less well characterized.

The transcription factor nuclear factor- $\kappa \mathrm{B}(\mathrm{NF}-\kappa \mathrm{B})$ is a key regulator of gene transcription that is involved in the control of cellular proliferation and apoptosis ${ }^{[6-9]}$. In most cell types, NF- $\mathrm{kB}$ is maintained in an inactive form in the cytoplasm by an association with its inhibitory protein, I $\kappa B \alpha$. A wide variety of extracellular signals may lead to the phosphorylation and degradation of I $\mathrm{KB} \alpha$ protein; degradation of I $\kappa \mathrm{B} \alpha$ frees NF- $\kappa \mathrm{B}$ to enter the nucleus and activate transcription of target genes ${ }^{[10]}$. In some cell types other than thyroid cells, the effects of NF-kB on cyclin D1 expression and cell cycle progression have been reported; these results indicate that NF-kB acts by increasing the abundance of cyclin $\mathrm{D} 1^{[11,12]}$. In addition, some growth factors, such as IGF-1, induce expression of NF- $\kappa \mathrm{B}$ activity in various cell types; this induction corresponds with a proliferative response ${ }^{[13,14]}$. These findings prompted us to investigate whether IGF-1 influences cyclin D1 expression in thyroid cells by affecting the activity of NF-kB.

The aim of the current study was to examine the signaling pathway related to IGF-1-mediated cyclin D1 expression in thyroid cells and its relationship to cell cycle control. Our results demonstrate that IGF-1 promotes cell cycle progression and upregulates cyclin D1 expression by stimulating the $\mathrm{PI} 3 \mathrm{~K} / \mathrm{NF}-\mathrm{kB}$ pathway in thyroid cells.

\section{Materials and methods}

Cell culture and treatments FRTL thyroid cells (ATCC catalog no. CRTL-1486) were grown in Coon's modified F12 media supplemented with $5 \%$ fetal bovine serum (Invitrogen, Carlsbad, CA, USA) and a mixture of six hormones: bovine TSH $(1 \mathrm{mU} / \mathrm{mL})$, insulin $(10 \mu \mathrm{g} / \mathrm{mL})$, hydrocortisol $(0.4 \mathrm{ng} / \mathrm{mL})$, transferrin $(5 \mu \mathrm{g} / \mathrm{mL})$, somatostatin $(10 \mathrm{ng} / \mathrm{mL})$, and glycyl- $L$-histidyl-L-lysine acetate (10 ng/mL) (hereafter termed "6H"; Sigma, St Louis, MO, USA). Fresh $6 \mathrm{H}$ medium was added every two or three days, and cells were passaged every 7-10 days. When grown to $90 \%$ confluence in $6 \mathrm{H}$ medium, the cells were then washed and starved in medium containing $0.2 \%$ fetal bovine serum in the absence of both TSH and insulin (4H medium) and were cultured for an additional two days before being used. In individual experiments, starved cells were washed twice with PBS, then IGF-1 was added as noted for $24 \mathrm{~h}$. In some experiments, the PI3K inhibitor LY294002 $(10 \mu \mathrm{mol} / \mathrm{L})$ or the NF- $\kappa B$ inhibitor BAY11-7082 (50 $\mu \mathrm{mol} / \mathrm{L}$; Sigma, St Louis, MO, USA), was added for $1 \mathrm{~h}$ prior to IGF-1 treat- ment. Cells that were maintained in $4 \mathrm{H}$ without any treatment were used as a control.

Western blotting After being washed with phosphatebuffered saline (PBS), FRTL cells were collected in a lysis buffer containing $1 \times \mathrm{PBS}, 1 \%$ nonylphenylpolyethylenglycol P-40 (NP-40), 0.1\% SDS, 5 mmol/L EDTA, 0.5\% sodium deoxycholate, $1 \mathrm{mmol} / \mathrm{L}$ sodium orthovanadate and 1 $\mathrm{mmol} / \mathrm{L}$ phenylmethylsulfonyl fluoride (PMSF). Cells were then centrifuged at $12000 \mathrm{r} / \mathrm{min}$ for $10 \mathrm{~min}$ at $4{ }^{\circ} \mathrm{C}$. The resulting supernatants (whole-cell lysates) were collected and either frozen at $-80^{\circ} \mathrm{C}$ or used immediately. Cytoplasmic proteins were collected with NE-PER nuclear and cytoplasmic extraction reagents (Pierce, USA). Protein concentrations were determined by bicinchoninic acid (BCA) protein assay (Pierce, USA). Samples $(60 \mu \mathrm{g})$ were heated for 30 min at $60^{\circ} \mathrm{C}$, then analyzed by $12 \%$ SDS-polyacrylamide gel electrophoresis (SDS-PAGE) and electroblotted onto nitrocellulose membranes. The membranes were blocked in 5\% nonfat milk for $1 \mathrm{~h}$ and then incubated with the specific primary antibody overnight at $4^{\circ} \mathrm{C}$, washed and incubated with the appropriate horseradish peroxidase-conjugated secondary antibody. After that, immune complexes were detected using the enhanced chemiluminescence method, and the same membrane was re-blocked with anti- $\beta$-actin monoclonal antibody. The immunoreactive bands were quantified using the AlphaImager 2200. Values were corrected by the absorbance of the internal control ( $\beta$-actin).

Immunofluorescence The location and expression of I $\mathrm{KB}$ (NF-kB inhibitory protein) were examined using immunofluorescence. FRTL-5 cells were seeded on polyornithinecoated glass coverslips and treated as described above. The antibody used was rabbit anti-IкB (Santa Cruz, USA). Nuclei were stained with 4,6-diamidino-2-phenylindole (DAPI) (Vector Laboratories, Burlingame, CA, USA). The resultant immunofluorescence was viewed under a fluorescence microscope (Leica Microsystems GmbH, Wetzlar, Germany). All images were acquired using the same intensity and photodetector gain to allow quantitative comparisons of the relative levels of immunoreactivity between sections.

Cell cycle analysis by fluorescence activated cell sorting (FACS) Cell cycle analysis was performed using FACS. Briefly, subconfluent thyroid cells were rendered quiescent by incubation in serum-free media for $48 \mathrm{~h}$ and then stimulated with or without inhibitors for $1 \mathrm{~h}$, followed by treatment with IGF-1 ( $50 \mathrm{ng} / \mathrm{mL})$ for $24 \mathrm{~h}$. Cells were harvested by trypsinization, washed with PBS and stained with propidium iodide (PI) using the Coulter DNA PREP ${ }^{\mathrm{TM}}$ reagents kit (Beckman Coulter, USA). Samples were analyzed by FACS 
on a Coulter Elite ESP (Beckman Coulter, USA) using standard filter sets. Results were expressed graphically and were quantified as the fraction of cells in $G_{0} / G_{1}, S$, or $G_{2} / M$ phase using Coulter cytologic software.

Data analysis All experiments were repeated at least three times independently. Values are given as means \pm SD. Data were analyzed using SPSS 10.0 software. Statistical significance was assessed by ANOVA and unpaired Student's $t$ test. A $P<0.05$ was considered to be statistically significant.

\section{Results}

The effect of IGF-1 on cyclin D1 expression and the involvement of the PI3K pathway To determine the effect of IGF-1 on cyclin D1 expression, FRTL cells were incubated with IGF-1, and the cyclin D1 protein expression was measured by Western blotting. These results demonstrated that the level of cyclin D1 protein was increased significantly following IGF-1 treatment $(P<0.05)$, indicating that in thyroid cells IGF-1 could up-regulate the cyclin D1 expression. Next, the pathway mediating the IGF-1-induced increase in the cyclin D1 level was examined by using a selective inhibitor of the PI3K pathway, LY294002. These results showed that LY204002 decreased the IGF-1-induced increase in the cyclin D1 protein expression by $40 \%$ (Figure 1).

The inhibitory effect of IGF-1 on IкBa proteins It is known that the activation of NF-kB is regulated, in part, through a cellular process involving degradation of its inhibitory protein $\mathrm{I} \kappa \mathrm{B} \alpha$, which allows NF- $\mathrm{kB}$ to translocate to the nucleus and trigger transcription. To study the effects of IGF-1 on NF-kB, immunofluorescence was performed on thyroid cells with a specific antibody to I $\mathrm{K} B \alpha$. As shown in Figure 2, intense staining for I $\mathrm{B} B$ in the cytoplasm was shown in the untreated cells, while treatment of FRTL cells with $50 \mathrm{ng} / \mathrm{mL}$ IGF- 1 resulted in a decrease in I $\mathrm{B} \boldsymbol{\alpha}$ expression as compared with the untreated cells $(P<0.05)$. Meanwhile, LY294002 pretreatment diminished the degradation of I $\kappa a$ that was induced by IGF-1 $(P<0.05)$. Furthermore, our previous study showed that IGF-1 pretreatment increased NF- $\kappa B$ DNA binding activity, which could be blocked by LY294002 (data not shown). Together, these results suggest that IGF-1 promotes the activation of NF-kB via PI3K.

Effect of NF- $\kappa B$ inhibitor BAY1 1-7082 on cyclin D 1 expression stimulated by IGF-1 An essential role for $\mathrm{NF}-\mathrm{kB}$ in the regulation of cyclin D1 expression has been reported in several cell models. The NF-kB inhibitor BAY117082 can prevent $\mathrm{I} \kappa \mathrm{B} \alpha$ phosphorylation and proteasomemediated I $\mathrm{I} B \alpha$ degradation, resulting in the inactivation of NF-kB. Therefore, in the current study, BAY11-7082 was

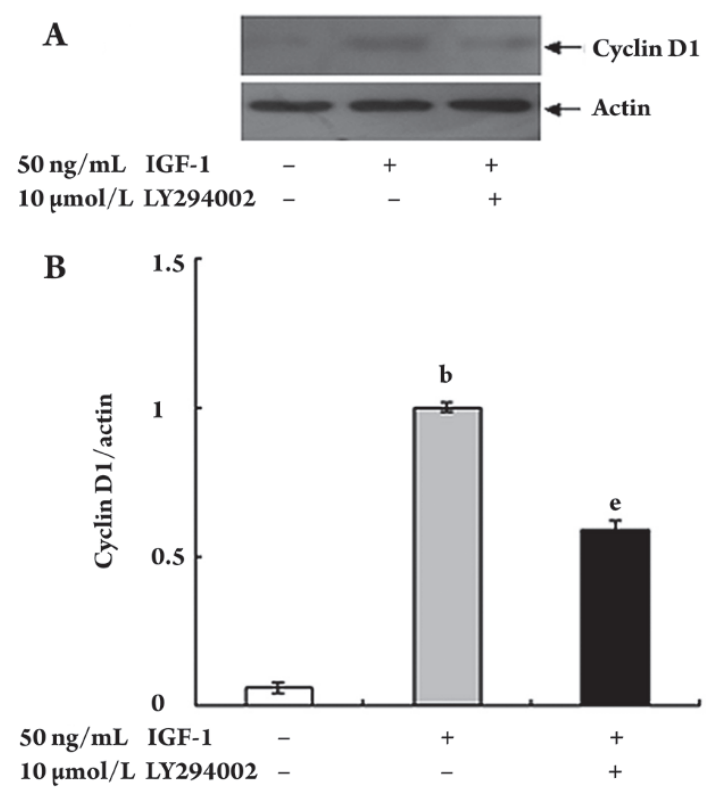

Figure 1. Expression of cyclin D1 in FRTL cells. In the presence or absence of LY294002 (10 $\mu \mathrm{mol} / \mathrm{L})$, starved cells were pretreated with IGF-1 for $24 \mathrm{~h}$. Equal amounts of total protein were loaded and a Western blot was performed to measure cyclin D1 protein expression. (A) A representative Western blot result is shown. (B) Expression of cyclin D1 was quantified by densitometric analysis and expressed as mean \pm SD for three separate experiments. ${ }^{b} P<0.05 v s$ the control group, ${ }^{\mathrm{e}} \mathrm{P}<0.05$ vs the IGF-1-treated group.

used to determine the role of NF-kB in the IGF-1-stimulated cyclin D1 expression pathway in thyroid cells. The effect of IGF-1 on cyclin D1 protein levels was significantly blunted by BAY11-7082 $(P<0.05)$. Furthermore, in FRTL cells cultured in the presence of IGF-1 with LY294002 and BAY117082 together, a more significant reduction of cyclin D 1 protein level was observed as compared to cells cultured in the presence of IGF-1 with LY294002 or BAY11-7082 alone (Figure 3). Thus, activation of the NF- $\mathrm{B}$ pathway appears to be required for IGF-1 mediated upregulation of cyclin D1 expression.

The involvement of PI3K and the NF- $\mathrm{kB}$ pathway on cell cycle progression stimulated by IGF- 1 The ability of IGF-1 to cause entry into the cell cycle was confirmed by FACS analysis of cell distribution in each phase of the cell cycle. When FRTL cells were rendered quiescent by a 48 -h incubation in starvation media, $79.5 \% \pm 4.3 \%$ of cells were in $\mathrm{G}_{0} / \mathrm{G}_{1}, 17.7 \% \pm 3.0 \%$ were in $\mathrm{G}_{2} / \mathrm{M}$, and almost no cells were in $S$ phase. When the quiescent FRTL cells were incubated for $24 \mathrm{~h}$ with $50 \mathrm{ng} / \mathrm{mL}$ IGF-1, the proportion of cells in $\mathrm{G}_{0} / \mathrm{G}_{1}$ phase was decreased to $73.9 \% \pm 2.3 \%$, the proportion in $S$ phase was increased to $6.2 \% \pm 1.2 \%(P<0.05)$, and the 


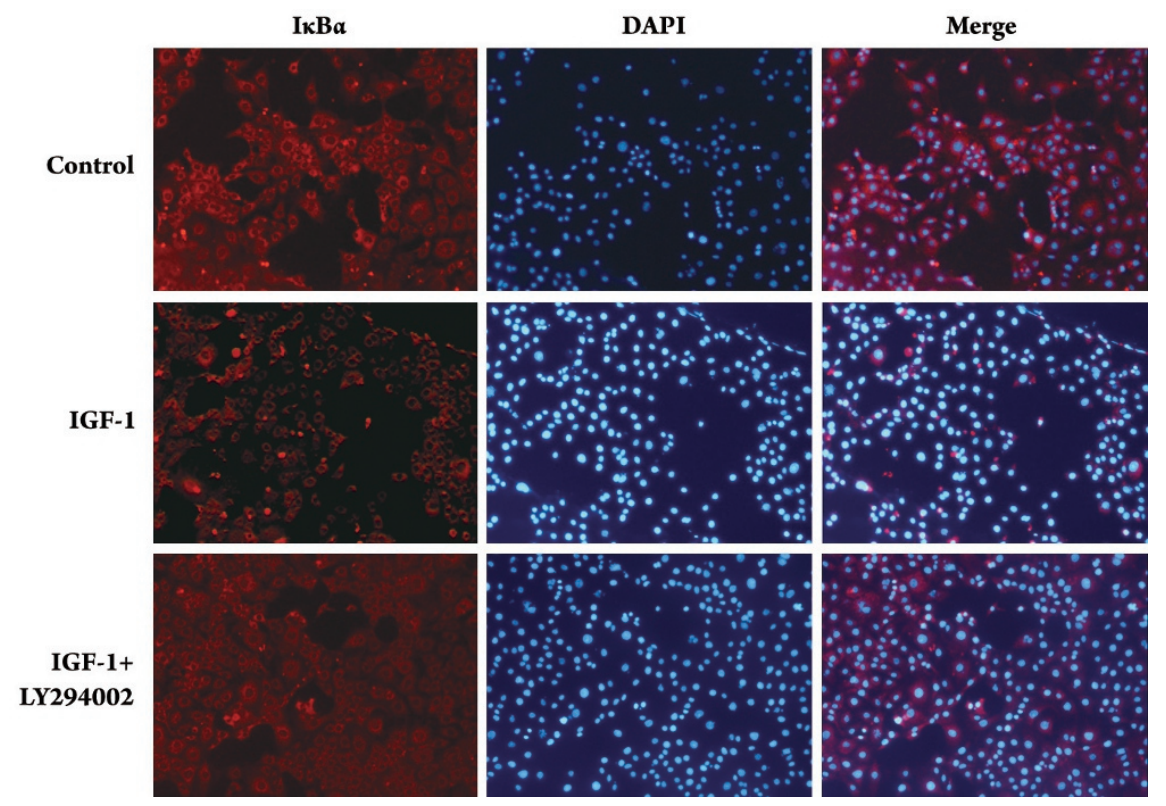

Figure 2. The immunofluorescence of $\mathrm{I} \mathrm{B} \alpha$ in FRTL-5 cells. Following 48 h of starvation and pretreatment for $1 \mathrm{~h}$ with the PI3K inhibitor LY294002, subconfluent FRTL cells were treated with $50 \mathrm{ng} / \mathrm{mL}$ IGF-1 in the absence or presence of inhibitor for $24 \mathrm{~h}$. The staining of $\mathrm{I} \kappa \mathrm{B} \alpha$ was detected by immunofluorescence with anti-I $\mathrm{B} \alpha$ antibody (TRITC-conjugated). The blue in the images depicts the DAPI-stained nuclei. The merged images were obtained after superposition of the red $(\mathrm{I} \kappa \mathrm{B} \alpha)$ and blue (DAPI) channels. The images are representative of three separate experiments. Magnification: $\times 100$. proportion in $\mathrm{G}_{2} / \mathrm{M}$ phase was increased to $19.9 \% \pm 1.9 \%$. However, in the presence of inhibitors of LY294002 or BAY11-7082, IGF-1-mediated cell cycle progression was blocked. Compared with the proportion in IGF-1-only treated cells, the proportion of cells in $S$ phase was decreased to $3.4 \% \pm 1.1 \%$ and $2.9 \% \pm 1.7 \%$, respectively (both $P<0.05$ ). Furthermore, the proportion of cells in $\mathrm{G}_{0} / \mathrm{G}_{1}$ was increased to $79.4 \% \pm 3.2 \%$ and $78.3 \% \pm 3.0 \%$, respectively. Furthermore, in FRTL cells cultured in the presence of IGF-1 together with LY294002 and BAY11-7082, a reduction of cells in S phase $(2.5 \% \pm 1.3 \%)$ was observed, as compared to cells cultured in the presence of IGF-1 with LY294002 or BAY11-7082 alone. These results show that the PI3K and NF- $\kappa \mathrm{B}$ pathways are involved in IGF-1-induced cell cycle progression from $G_{0} / G_{1}$ to $S$ phase (Figure 4).

\section{Discussion}

The main finding of the present study is that stimulation of IGF-1 promotes cell cycle progression and upregulates cyclin D1 expression in cultured FRTL cells. Further research shows, for the first time, that pleiotropic transcription factor NF- $\mathrm{NB}$ is implicated in the signaling pathway of IGF-1-mediated upregulation of cyclin D1 protein in normal thyroid cells.

IGF-1 plays important roles in promoting survival and proliferation of a variety of cell types. IGF-1 stimulates quiescent cells to pass through $G_{1}, S$, and $G_{2} / M$ phases to complete the cell cycle by regulating cyclins. Cyclin D1, which belongs to the D group of cyclins, is expressed in all mammalian cells except lymphocytes and myeloid cells ${ }^{[20]}$. In some cell types, cyclin D1 is rate-limiting for cell cycle progression and its abundance varies with the cell cycle ${ }^{[15,16]}$. Here we found that in quiescent FRTL cells cyclin D1 was barely detectable, whereas pretreatment with IGF-1 caused a distinct increase in cyclin D1 expression. Furthermore, our current study showed that, under quiescent conditions, most thyroid cells remained in $G_{0}$, and pretreatment with IGF-1 for $24 \mathrm{~h}$ increased the number of cells in $S$ phase to a small extent, with a decrease in the number of cells in $G_{0} / G_{1}$. This indicates that IGF-1 promotes cell entry into $S$ phase in thyroid cells. Our results were not consistent with those of a study of glomerular mesangial cells, which showed that IGF-1 increased cyclin D1 levels to promote $G_{0} / G_{1}$ progression but did not induce $G_{1}$ to $S$ phase transition ${ }^{[17]}$. This discrepancy may be a result of the different cell types used in the two studies.

The biological actions of IGF-1 are mediated by activation of the IGF-1 receptor (IGF-1R). Signals that transferred from the interactions between IGF-1 and the IGF-1R are required for cell cycle progression ${ }^{[18-20]}$. IGF-1 stimulates two major signal transduction pathways: the PI3K pathway and the MAPK pathway. Our experiments demonstrated that blocking the PI3K pathway with the PI3K inhibitor LY294002 prevented the progression from $G_{1}$ to $S$ phase in response to IGF-1. Moreover, LY294002 also diminished the expression of cyclin D1 stimulated by IGF-1. This was supported by a previous study suggesting that the effect of 
A

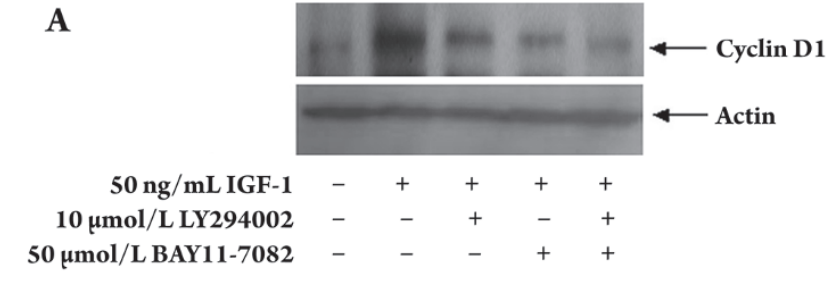

B

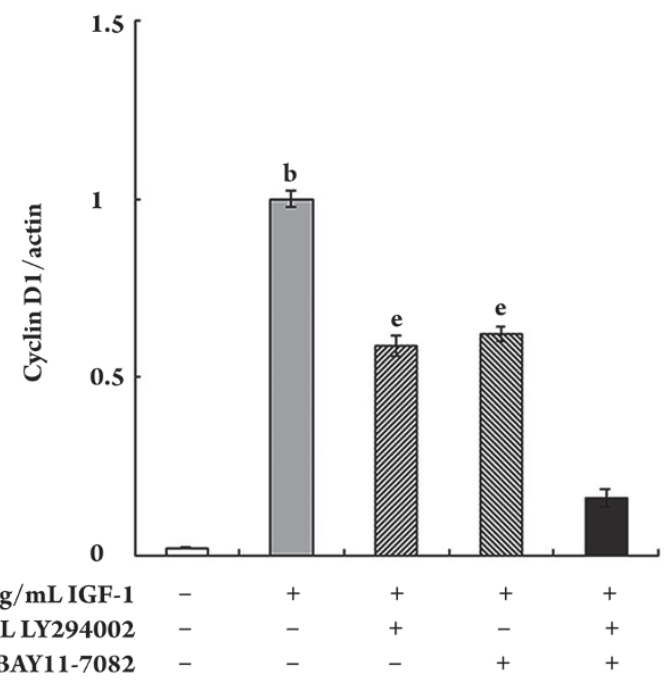

Figure 3. Effect of LY294002 and BAY11-7082 on protein levels of cyclin D1. Starved cells were treated with IGF-1 $(50 \mathrm{ng} / \mathrm{mL})$ for $24 \mathrm{~h}$. LY294002 (10 $\mu \mathrm{mol} / \mathrm{L})$ and/or BAY11-7082 (50 $\mu \mathrm{mol} / \mathrm{L})$ were added $1 \mathrm{~h}$ prior to IGF-1 treatment. Whole-cell lysates were probed for cyclin D1 and $\beta$-actin by Western blotting. Equal amounts of protein were loaded to allow for direct comparisons of cyclin D1 levels in different groups. $\beta$-actin was used as a loading control. (A) A representative Western blot is shown. (B) A histogram plot represents the densitometric analysis corresponding to the means \pm SD of three independent experiments. ${ }^{\mathrm{b}} \mathrm{P}<0.05$ vs the control group, ${ }^{\mathrm{e}} \mathrm{P}<0.05$ vs the IGF-1 group.

IGF-1 on cyclin D1 expression required PI3K activation ${ }^{[21]}$. Taken together, our results extend the previous observations in showing that PI3K is involved in the regulation by IGF-1 in cell cycle progression as well as in cyclin D1 expression. Furthermore, IGF-1 also activates the MAPK pathway through activation of Ras and a cascade of successive protein phosphorylation reactions, which also play important roles in proliferative thyroid diseases. However, whether the RasMAPK signaling pathway is involved in IGF-1-induced cell cycle progression needs further investigation ${ }^{[22]}$.

The transcriptional factor NF- $\mathrm{kB}$ has been implicated in the regulation of cellular proliferation. Enhanced NF-kB activity, which is apparent during the $\mathrm{G}_{0} / \mathrm{G}_{1}$ transition in fibroblasts, is induced by mitogenic stimuli in $\mathrm{G}_{0}$ arrested $3 \mathrm{~T} 3$ fibroblasts ${ }^{[23,24]}$. It has recently been reported that acti- vation of NF-kB is involved in the IGF-1-mediated neuronal survival against oxidative stress and insulin anti-apoptotic activity $^{[13,14]}$. Based on these reports, and because IGF-1 is an essential factor for the proliferation of FRTL cells, we speculate that NF- $\mathrm{kB}$ may be involved in the effect of IGF-1 on FRTL cells. To explore whether NF- $k B$ is a downstream target of IGF-1 when inducing cyclin D1 expression, NF- $\mathrm{kB}$ cytoplasmic inhibitory protein, I $\kappa \mathrm{B} \alpha$, was measured after stimulation with IGF-1. As compared with unstimulated cells, an obvious decrease in I $\mathrm{KB} \alpha$ expression was found in the cells treated with IGF-1. Together with our previous findings that IGF-1 increased NF- $\kappa B$ DNA binding activity in FRTL cells, we speculate that the induction of NF- $\mathrm{KB}$ driven gene expression by IGF-1 is one mechanism for promoting proliferation and cell cycle progression in thyroid cells.

Some previous experiments indicate that NF- $\mathrm{BB}$ acts by increasing the abundance of cyclin $\mathrm{D} 1$ protein, and subsequently affects $\mathrm{G}_{1}$-to-S phase transition. Methods for inhibiting NF- $\kappa B$ activity are commonly used to study the role of NF- $\kappa \mathrm{B}$ factors in controlling the cell cycle and cyclin D1 expression. In the present study, the influence of the NF- $\mathrm{kB}$ signaling pathway on cyclin D1 expression was observed by inhibiting NF- $\kappa B$ activation with a selective inhibitor, BAY11-7082. Our results showed that BAY11-7082 significantly reduced IGF-1-stimulated cyclin D1 expression, consistent with those of a study in human parathyroid tumors that showed that blockade of the NF-kB pathway caused an obvious decrease in cyclin D1 expression ${ }^{[25]}$. All together, our results suggest that in normal thyroid cells, the activation of NF- $\mathrm{kB}$ mediates the cyclin D1 expression induced by IGF-1.

Since the current study has demonstrated that PI $3 \mathrm{~K}$ and NF- $\mathrm{kB}$ are both implicated in the signaling pathway of cyclin D1 expression mediated by IGF-1, we further explored whether both processes were mediated by a common pathway. To date, the role of PI3K in regulating NF- $\mathrm{KB}$ transactivation remains controversial. Some studies have shown that the inhibition of PI3K increased DNA-binding activity of NF- $\mathrm{KB}$ in monocyte-derived dendritic cells ${ }^{[26]}$, whereas others indicated that PI3K activation could promote the activation of NF- $\mathrm{kB}^{[27]}$. In our present experiment, upon investigating the effect of LY294002 on I KB $\alpha$ expression induced by IGF-1, it turned out that the PI3K inhibitor blocked the IGF1 -induced decrease in NF- $\mathrm{KB}$ inhibitory protein expression, indicating that NF- $\mathrm{kB}$ is a downstream target involved in the IGF-1/PI3K pathway in this normal thyroid line.

In conclusion, this study shows that IGF-1 stimulates FRTL thyroid cells to progress through the $G_{1}$ phase of the 

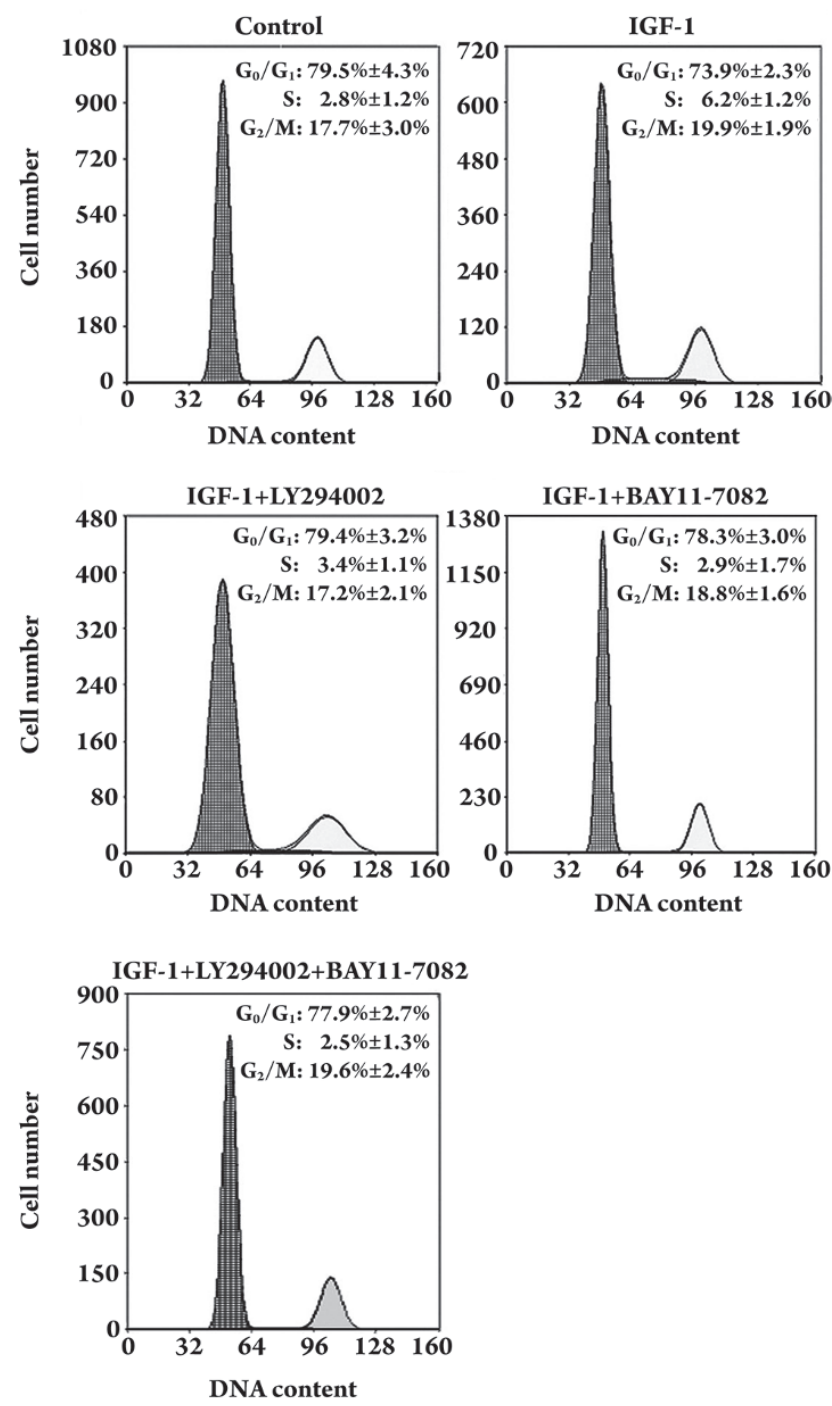

Figure 4. Fluorescence-activated cell sorting (FACS) analysis of cell cycle distribution. Following $48 \mathrm{~h}$ of starvation and pretreatment for 1 $\mathrm{h}$ with $10 \mu \mathrm{mol} / \mathrm{L}$ LY294002 or $50 \mu \mathrm{mol} / \mathrm{L}$ BAY11-7082, subconfluent FRTL cells were treated with $50 \mathrm{ng} / \mathrm{mL}$ IGF-1 in the absence or presence of inhibitor for $24 \mathrm{~h}$. The cells were harvested by trypsinization and subjected to FACS analysis as described in Materials and Methods. Results for quiescent and treated cells were expressed as the percentage of total cells in $G_{0} / G_{1}, S$, or $G_{2} / M$ phase of the cell cycle. Values represent the means $\pm \mathrm{SD}$ of three separate experiments.

cell cycle and exerts its effects on the $\mathrm{G}_{1}$ phase by upregulating cyclin D1 expression. Our findings also provide novel evidence that the IGF-1/PI3K/NF- $\mathrm{kB}$ pathway is involved in inducing the expression of cyclin D1 in normal thyroid cells. This involvement may explain how IGF-1 plays an important role in the growth of thyroid cells. However, the precise underlying mechanisms and the potential involvement of other signaling pathways still need further investigation.

\section{Acknowledgement}

Project supported by the National Natural Science Foundation of China (30672748) and Shandong Administration of Traditional Chinese Medicine (2005-070).

\section{Author contribution}

Jia-jun ZHAO and Ling GAO desinged research; Meng REN and Xia ZHONG performed research; Chun-yan MA and Ying SUN contributed new analytical tools and reagents; Qing-bo GUAN, Bin CUI, Jun GUO, and Hai WANG analyzed data; Meng REN, Xia ZHONG, and Ling GAO wrote the paper.

\section{References}

1 Graña X, Reddy EP. Cell cycle control in mammalian cells: role of cyclins, cyclin dependent kinases (CDKs), growth suppressor genes and cyclin-dependent kinase inhibitors (CKIs). Oncogene 1995; 11: 211-9.

2 Sherr CJ, Kato J, Quelle DE, Matsuoka M, Roussel MF. D-type cyclins and their cyclin-dependent kinases: G1 phase integrators of the mitogenic response. Cold Spring Harb Symp Quant Biol 1994; 59: 11-9.

3 Lantsov D, Meirmanov S, Nakashima M, Kondo H, Saenko V, Naruke Y, et al. Cyclin D1 overexpression in thyroid papillary microcarcinoma: its association with tumour size and aberrant $\beta$-catenin expression. Histopathology 2005; 47: 248-56.

4 Kofidis T, de Bruin JL, Yamane T, Balsam LB, Lebl DR, Swijnenburg RJ, et al. Insulin-like growth factor promotes engraftment, differentiation, and functional improvement after transfer of embryonic stem cells for myocardial restoration. Stem Cells 2004; 22: 1239-45.

5 Radcliff K, Tang TB, Lim J, Zhang Z, Abedin M, Demer LL, et al. Insulin-like growth factor-1 regulates proliferation and osteoblastic differentiation of calcifying vascular cells via extracellular signalregulated protein kinase and phosphatidylinositol 3-kinase pathways. Circ Res 2005; 96: 398-400.

6 Ghosh S, May MJ, Kopp EB. NF-kappaB and Rel proteins: evolutionarily conserved mediators of immune responses. Annu Rev Immunol 1998; 16: 225-60.

7 Barkett M, Gilmore TD. Control of apoptosis by Rel/NF-kappaB transcription factors. Oncogene 1999; 18: 6910-24.

8 Karin M, Ben-Neriah Y. Phosphorylation meets ubiquitination: the control of NF-kappaB activity. Annu Rev Immunol 2000; 18: 621-63.

9 Tak PP, Firestein GS. NF-kappaB: a key role in inflammatory diseases. J Clin Invest 2001; 107: 7-11.

10 Pahl HL. Activators and target genes of Rel/NF-kappaB transcription factors. Oncogene 1999; 18: 6853-66.

11 Hinz M, Krappmann D, Eichten A, Heder A, Scheidereit C, Strauss M. NF-kappaB function in growth control: regulation of cyclin D1 expression and $\mathrm{G}_{0} / \mathrm{G}_{1}$-to-S-phase transition. Mol Cell Biol 1999; 19: $2690-8$. 
12 Guttridge DC, Albanese C, Reuther JY, Pestell RG, Baldwin AS Jr. NF-kappaB controls cell growth and differentiation through transcriptional regulation of cyclin D1. Mol Cell Biol 1999; 19: 5785-99.

13 Bertrand F, Philippe C, Antoine PJ, Baud L, Groyer A, Capeau $\mathrm{J}$, et al. Insulin activates nuclear factor kappaB in mammalian cells through a Raf-1-mediated pathway. J Biol Chem1995; 270: 24435-41.

14 Heck S, Lezoualc'h F, Engert S, Behl C. Insulin-like growth factor1 -mediated neuroprotection against oxidative stress is associated with activation of nuclear factor kappaB. J Biol Chem 1999; 274: 9828-35.

15 Xiong W, Pestell RG, Watanabe G, Li J, Rosner MR, Hershenson MB. Cyclin D1 is required for $S$ phase traversal in bovine tracheal myocytes. Am J Physiol 1997; 16: L1205-10.

16 Beier F, Lee RJ, Taylor AC, Pestell RG, LuValle P. Identification of the cyclin D1 gene as a target of activating transcription factor 2 in chondrocytes. Proc Natl Acad Sci USA 1999; 96: 1433-8.

17 Jiang Y, Cheng DW, Levi E, Singh LP. IGF-1 increases laminin, cyclin D1, and P21Cip1 expression in glomerular mesangial cells: An investigation of the intracellular signaling pathway and cellcycle progression. J Cell Biochem 2006; 98: 208-20.

18 Wilker E, Lu J, Rho O, Carbajal S, Beltrán L, DiGiovanni J. Role of PI3K/Akt signaling in insulin-like growth factor-1 (IGF-1) skin tumor promotion. Mol Carcinog 2005; 44: 137-45.

19 Shelton JG, Steelman LS, White ER, McCubrey JA. Synergy between PI3K/Akt and Raf/MEK/ERK pathways in IGF-1R mediated cell cycle progression and prevention of apoptosis in hematopoietic cells. Cell Cycle 2004; 3: 372-9.

20 Zaka M, Rafi MA, Rao HZ, Luzi P, Wenger DA. Insulin-like growth factor- 1 provides protection against psychosine-induced apoptosis in cultured mouse oligodendrocyte progenitor cells using primarily the PI3K/Akt pathway. Mol Cell Neurosci 2005; 30: 398-407.

21 Saito J, Kohn AD, Roth RA, Noguchi Y, Tatsumo I, Hirai A, et al. Regulation of FRTL-5 thyroid cell growth by phosphatidylinositol (OH) 3 kinase-dependent Akt-mediated signaling. Thyroid 2001; 11:339-51.

22 Segev DL, Umbricht C, Zeiger MA. Molecular pathogenesis of thyroid cancer. Surg Oncol 2003; 12: 69-90.

23 Baldwin AS Jr, Azizkhan JC, Jensen DE, Beg AA, Coodly LR. Induction of NF-kappaB DNA-binding activity during the G0to-G1 transition in mouse fibroblasts. Mol Cell Biol 1991; 11: 4943-51.

24 Duckett CS, Perkins ND, Leung K, Agranoff AB, Nabel GJ. Cytokine induction of nuclear factor kappa $\mathrm{B}$ in cycling and growth-arrested cells. Evidence for cell cycle-independent activation. J Biol Chem 1995; 270: 18836-40.

25 Corbetta S, Vicentini L, Ferrero S, Lania A, Mantovani G, Cordella $\mathrm{D}$, et al. Activity and function of the nuclear factor kappaB pathway in human parathyroid tumors. Endocr Relat Cancer 2005; 12: 929-37.

26 Aksoy E, Vanden Berghe W, Detienne S, Amraoui Z, Fitzgerald KA, Haegeman G, et al. Inhibition of phosphoinositide 3-kinase enhances TRIF-dependent NF-kappa B activation and IFN- $\beta$ synthesis downstream of Toll-like receptor 3 and 4 . Eur J Immunol 2005; 35: 2200-9.

27 Jimenez Del Rio M, Velez-Pardo C. Insulin-like growth factor-1 prevents Abeta[25-35]/( $\left.\mathrm{H}_{2} \mathrm{O}_{2}\right)$ - induced apoptosis in lymphocytes by reciprocal NF-kappaB activation and p53 inhibition via PI3K-dependent pathway. Growth Factors 2006; 24: 67-78. 